$$
D P-461
$$

INSTRUMENTS

(TID-4500, 15tn Ed.)

\title{
A COLORIMETER FOR IN-LINE ANALYSIS OF URANIUM AND PLUTONIUM SOLUTIONS
}

\author{
by \\ Donald W. Colvin
}

March 1960

\author{
E. I. du Pont de Nemours \& Co. \\ Explosives Department - Atomic Energy Division \\ Technical Division - Savannah River Laboratory \\ Printed for \\ The United States Atomic Energy Commission \\ Contract $\operatorname{AT}(07-2)-1$
}

Approved by

J. N. Wilson, Research Manager

Applied Physics Division
This document is

PUBLICLY RELEASABLE

$B$ ans streb

Authorizing Official

Date: 


\section{DISCLAIMER}

This report was prepared as an account of work sponsored by an agency of the United States Government. Neither the United States Government nor any agency Thereof, nor any of their employees, makes any warranty, express or implied, or assumes any legal liability or responsibility for the accuracy, completeness, or usefulness of any information, apparatus, product, or process disclosed, or represents that its use would not infringe privately owned rights. Reference herein to any specific commercial product, process, or service by trade name, trademark, manufacturer, or otherwise does not necessarily constitute or imply its endorsement, recommendation, or favoring by the United States Government or any agency thereof. The views and opinions of authors expressed herein do not necessarily state or reflect those of the United States Government or any agency thereof. 


\section{DISCLAIMER}

Portions of this document may be illegible in electronic image products. Images are produced from the best available original document. 


\begin{abstract}
A colorimeter is described that can be used to monftor process solutions continuously for urany 1 nitrate or plutonium nitrate concentration. The instrument was tested under plant conditions in the concentration range from 0.1 to 70 grams of uranium per liter and 0.1 to 10 grams of plutonium per liter. The instrument error was $\pm 1 \%$ of the span, but errors of 15 to $20 \%$ can be caused by other variables such as acidity and other salts present.
\end{abstract}




\section{CONTENTS}

$\underline{\text { Page }}$

Introduction 4

Summary 4

Discussion 4

General Principles 4

Design of the Instrument 5

General Design 5

Component Design 6

Calibration $\quad 7$

Standardization 8

Evaluation of the Instmument 9

Bibliography 10

Appendix - Calculation of Optimum Cell Thickness Il

\section{LIST OF FIGURES}

Figure

1 Functional Diagram of the Colorimeter 13

2 Photograph of the Colorimeter Optics Housing 14

3 Photograph of the Colorimeter Measuring System 15

4 Light Power Supply 16

5 Sample Cell 17

6 Preamplifier Circuit 18

$7 \quad$ Amplifier Circuit 19

8 Modification of Brown Recorder 20

9 Solenoid Power Supply 21

10 Calibration Curves for Uranyl Nitrate 22

11 Calibration Curves for Plutonium Nitrate 22

12 Effect of Temperature on Colorimeter Measurement 23

13 Effect of Turbidity on Colorimeter Measurement 23

14 Effect of Nitric Acid on Colorimeter Measurement 23 


\section{A COLORIMETER FOR IN-LINE ANALYSIS OF URANIUM AND PLUTONIUM SOLUTIONS}

\section{INTRODUCTION}

In the process of separating uranium and plutonium from spent reactor fuel elements, it is advantageous to monitor the concentration of these products in the various process streams. A gamma absorptometer was designed for this application(1) but only concentrations greater than about 10 grams per liter can be measured with this instrument. Furthermore, the gamma absorptometer cannot operate satisfactorily when the gamma radiation from the sample cell exceeds about 25-50 $\mathrm{mr}$ /hour.

A colorimeter was designed to satisfy the need for an instrument to monitor the lower concentrations and to operate in a field of high radiation.(2) This early instrument proved the feasibility of using a colorimeter to monitor a process stream continuously for uranium concentration. However, some design improvements were needed to decrease the zero drift, to provide a remote method of standardization, to compensate more effectively for turbidity in the solution, and to compensate for fouling of the optical components. This report describes a colorimeter that avoids these shortcomings of the earlier design.

\section{SUMMARY}

The new instrument uses the dual-beam principle to compensate for darkening of optical components and for turbidity in the solution. A pulsating light source and $A C$ amplifiers are used in the measuring system to eliminate the drift that would result with a DC system. A method of remote standardization is included in the instrument, which permits a periodic check and readjustment of the calibration.

The colorimeter was used to measure the concentration of either uranyl nitrate or plutonium nitrate in solution. The instrument was tested under plant conditions with calibrations in the range from 0.1 to 10 grams of $\mathrm{Pu}(\mathrm{III})$ or $\mathrm{Pu}(\mathrm{IV})$ per liter and from 0.1 to 70 grams of uranium per liter. The accuracy of the measurements was found to be limited by the effects of extraneous solution variables rather than instrument noise or drift. The combined noise and drift produced an error of about $\pm 1 \%$ of the recorder span, while variations in temperature, turbidity, and nitric acid concentration in the solution can produce errors of 15 to $20 \%$ of the span.

\section{DISCUSSION}

\section{GENERAL PRINCIPLES}

A colorimeter may be used to measure the concentration of a chemical in a solution if the chemical imparts a characteristic color to the solution. The colorimeter optical system isolates a narrow wave 
band of Ilght at a selected absorption peak for the chemical that is measured. The intensity of the transmitted light at the absorption wave length is a function of the concentration of the chemical in the solution. When only the light at this wave length is used, Beer's law is obeyed and maximum sensitivity is obtained for the instrument. Use of the narrow wave length band usually makes possible the elimination of the absorption effects of other chemicals in the solution. However, the effect of some chemicals cannot be eliminated if they change the complex ion formation of the chemical being measured. This is the case when uranyl nitrate is measured in a solution containing nitric acid.

A more stable colorimeter can be made if the dual-beam principle is utilized. This is usually accomplished by comparing the light intensity at an absorption wave length with the intensity of a reference beam from the same light source. The two beams are obtained by passing a beam of white light through the soiution and then separating the beam into two parts. Filters are used to isolate an absorption wave length as well as a reference wave length. The reference filter is selected to pass only light at a wave length that is not absorbed by any chemicals in the solution. The two beams may then be compared by taking the ratio of their intensities to obtain an indication of the concentration of the chemical being measured. In this way, the instrument compensates for changes in the transmitted light intensity caused by darkening of the light bulb, fouling of optical components, and turbidity in the solution.

\section{DESIGN OF THE INSTRUMENT}

\section{GENERAL DESIGN}

The colorimeter described here is a dual-beam instrument that uses a pulsating light source. As a result, the instrument is unaffected by changes in phototube dark current and, since AC amplifiers can be used in the measuring circult, the drift that usually results from using DC amplifiers is eliminated. The pulsating light is obtained by turning the light on and off with a synchronous multivibrator that operates at a frequency of 15 cycles per second. The light is collimated and passed through the sample cell. The light beam is then divided by a beam splitter to produce an absorption beam and a reference beam. These beams pass through interference filters that 1solate a 7-10 $\mathrm{m \mu}$ band of light at the specifled wave lengths. The light beams then fall on phototubes, which produce electrical signals proportional to the light intensity. The resulting electrical signals are amplified by a preamplifier located in the optics housing and are then fed to a remotely located amplifier. The amplified currents are indicated on separate ammeters, and the ratio of the absorption to the reference current is indicated on a recorder. The recorder is wired so that an upscale deflection is obtained for increased concentration of the chemical being measured. The complete instrument is shown schematically in Figure 1. 
The instrument is standardized by energizing two rotary solenolds that rotate mirrors into the light beam to divert the beam around the sample cell. In the standardizing position, the current indicated on the ammeter in each channel and the recorder reading should be the same value that they had at the initial calibration. If, during a standardization check, the readings are observed to have changed, the amplifier gain controls can be adjusted to obtain the readings determined previously so that the instrument is readjusted to the original calibration.

\section{COMPONENT DESIGN}

The colorimeter consists of two groups of components. The first group is located at the solution sampling point and consists of the optics housing and the power supply for the light source. The optical system, sample cell, and preamplifier are all located in the optics housing. A photograph of the optics housing is shown in Figure 2. The second group of components may be located remotely and include the amplifier, the recorder, and the solenoid power supply. A photograph of these components is shown in Figure 3.

\section{Optical System}

A diagram of the optical system is shown in Figure 1. The light path is indicated for both the measuring and the standardizing positions. The light bulb is a GE \#2331 prefocused headlight bulb, which should last for at least three months provided it is well ventilated. The transmission wave lengths of the interference filters depend on the chemicals being measured. The table in Figure 1 gives the absorption and reference wave lengths for $\mathrm{UO}_{2}\left(\mathrm{NO}_{3}\right)_{2}$, and for $\mathrm{Pu}$ (III) and $\mathrm{Fu}(\mathrm{IV})$. The optical parts of the system can withstand gamma activity from the sample of up to 16 roentgens per hour at one inch for one year if the lenses and cell windows are made from nonbrowning glass and front surface mirrors are used.

\section{Light Power Supply}

The voltage for the light source is obtained from a 6.3-volt 60-cycle supply that is turned on and off 15 times per second. The power is intermuted with a relay located in the plate circuit of a $6 \mathrm{~L} 6$ vacuum tube that is controlled by a synchronous multivibrator. A diagram of the circuit is shown in Figure 4. The 10K adjustable resistor must be adjusted to obtain the wave form shown on the circuit diagram.

\section{Sample Cell}

The sample cell was designed for in-line installation and consists of a stainless steel block that contains a cylindrical sample compartment. Inlet and outlet tubes are provided for continuous circulation of a sample stream. Glass windows are used to cover the sample compartment 
and allow transmission of the light beam through the solution. The cell is constructed so that the glass windows seat against the steel block to maintain a constant cell thickness. A leaktight seal is made with gaskets at the outslde surface of the glass. A drawing of the cell is shown in Figure 5 .

The thickness of the sample cell is dependent on the chemical to be measured and the concentration range to be covered. The thickness is usually made optimum for a concentration at the center of the absorption range to be covered. The cell thickness for maximum sensitivity at a given concentration may be calculated from the following equation, which is derived in the Appendix.

Cell thickness $=(\text { molar extinction coeff. })^{-1} \times$ (concentration $^{-1}$

Preamplifier and Amplifier

The clrcult diagram of the preamplifier 1s shown in Figure 6 . This unit is located in the bottom of the optics housing and can be easily removed for replacement purposes. The clrcuit contains a stage of amplification and a cathode follower output for both the absorption and reference channels.

A circult diagram of the amplifier is shown in Figure 7 . This circuit contains a stage of amplification, a cathode follower, and a rectifier circuit for each channel. A twin " $T$ " filter is used in a negat1ve feedback loop to cancel out unwanted signals of other frequencies. After amplification, the absorption and reference signals are rectified and sent to the ratio recorder. A Brown recorder was converted to a ratio recorder as shown in the circuit diagram in Figure 7 . A $5 K$ potentiometer to adjust the recorder ratio is located in the amplifier circuit. A Helipot was geared to the recorder balance motor and used as the slide wire. A photograph of this modification is shown in Figure 8 .

\section{Solenoid Power Supply}

A solenold power supply is used as the voltage source to turn the rotary solenoids during standardization. When the "On" button is pushed, the solenoids are energized for a perlod of about three minutes. At the end of this time a thermal delay relay turns them off. The time delay is used because the solenolds produce excessive heat if used continuously, and in addition, the automatic cutoff prevents leaving the mirrors in the standardizing position. The voltage can be turned off before the three minutes is up by pushing the "Off" button. A diagram of this circuit is shown in Figure 9.

\section{CALIBRATION}

Before a colorimeter is placed in operation, the instrument must be adjusted and calibrated for the desired range of the chemical to be 
measured. The general method of calibration is to obtain solutions that cover the concentration range of the chemical to be measured and contain the normal concentration of any other interfering chemical that will be in the solution to be measured. Then, with alternate flow through the cell of two solutions that have the minimum and maximum concentrations, the instrument may be adjusted so that these concentrations produce, respectively, zero and nearly full-scale readings on the recorder. This is accomplished by adjusting the gain controls and the recorder ratio control. The current in the absorption channel should be near, but should not exceed, the full-scale meter reading with the lowest concentration in the sample cell. The reference current should be adjusted to produce a mid-scale current reading. If a full-scale recorder deflection cannot be obtained for the desired concentration range, the sensitivity may be increased by inserting an appropriate resistor in series with the Helipot slide wire in the recorder. The resistor should be connected on the ground side of the Helipot. After these adjustments have been made, the calibration curve can be completed with the remaining solutions. Calibrations have been made with uranyl nitrate in the $r$ ange from 0.1 to 70 grams of uranium per liter and with plutonium(III) nitrate and plutonium(IV) nitrate in the range from 0.1 to 10 grams of plutonium per liter. These calibration curves are shown in Figures 10 and 11 .

In practice, the above calibration must be made in the laboratory. Therefore, it was necessary to devise a procedure for recalibrating an instrument after installation on a process stream. Calibration points were obtained by substituting standard optical filters in the light path in place of the solution immediately after the instrument is calibrated with standard solutions. The filters selected should have the same absorption characteristics as the material being measured so that on-scale current and recorder readings may be obtalned. Two such filters may be selected to correspond to concentrations near each end of the recorder scale. With the filters in place the current and recorder readings should be taken. The instrument may be recalibrated after installation by inserting one of the filters in the light beam and readjusting the amplifier gain and recorder ratio controls to reset the current and recorder readings to the values obtained with the filter during the initial calibration. The second filter may then be inserted to determine if the range of the instrument is correct. In practice it was easier to make the filter checks with the sample cell removed to eliminate the necessity of cleaning and drying the cell.

\section{STANDARDIZATION}

A method of standardization was included in the instrument so that a calibration check could be made without removing the sample cell from the optics housing and without the standard filters used as outlined in the previous section. During standardization, the light beam is diverted 
around the sample cell. The current and recorder readings for this condition should be recorded immediately after the instrument is calibrated. These values should be reproduced each time the instmment is standardized. If the instrument readings are not reproduced the gain controls may be adjusted to obtain the correct readings. However, some method must be provided to obtain an on-scale recorder reading in the standardizing position if zero concentration of the chemical being measured does not fall on the recorder scale. This may be accomplished by inserting a filter in the standardizing light path that has the same absorption properties as the chemical to be measured.

An alternate method of obtaining an on-scale recorder indication during standardization is to switch a second set of gain controls into the clrcuit at the same time the light beam is diverted around the sample cell. These controls should be adjusted after the instrument is calibrated to produce a convenient recorder reading. The instrument readings obtained may be used during subsequent standardization checks. If the instrument readings are not reproduced during standardization, the fine gain controls may be adjusted to obtain the correct readings. These fine gain controls are in the circuit during both measuring and standardizing so that if they are adjusted during standardization they produce a similar effect when the switch is returned to the measuring position. The instrument is thus returned to the original calibration.

\section{EVALUATION OF THE INSTRUMENT}

The colorimeter has been tested under actual plant conditions for use in measuring uranyl nitrate and plutonium nitrate. The precision ard accuracy of the measurements were found to be limited by the effect of other variables in the solutions rather than instrument noise or calibration drift. With the instrument calibrations shown in Figures 10 and 11 , the combined instrument noise and drift is about $\pm 1 \%$ of the recorder span. However, the effects of temperature, turbidity, and acid concentration may produce a much larger error. The effects of these variables have been determined in the laboratory for uranyl nitrate solutions.

The temperature effect was determined by calibrating the instrument with solutions at 28,40 , and $50^{\circ} \mathrm{C}$. The $22^{\circ} \mathrm{C}$ increase in temperature caused the reading for uranium to increase about $7 \%$. The effect w11I probably vary with sample cell thickness. This test was made with a cell thickness of $1-3 / 4$ inches. The calibration curves obtained at the different temperatures are shown in Figure 12.

The turbidity effect was determined by adding organic solvent to the uranyl nitrate solutions. The solvent was beaten into the solution and circulated rapidly through the colorimeter. The turbidity, which resulted from an addition of $0.3 \%$ solvent, caused the current at the 
absorption wave length to decrease by about 50\%. However, the reference current also decreased so that the ratio clrcult compensated for most of the change. The resulting change in the uranium indication was a maximum of about 5\%. The amount of solvent was increased to $0.6 \%$, which resulted in further decrease of the currents and increased the error to a maximum of about 10\%. The results of this test are plotted in Figure 13.

The effect of the organic solvent was reduced to less than $1 \%$ by installing a separator-degasser in the inlet sample line. This device, which contains a decanting system, is similar to a degasser described in a previous report $(3)$.

The acid effect on the instrument was determined by varying the nitric acid concentration from 0 to 1 molar in the uranyl nitrate solutions. The results as shown in Figure 14 indicate that an increase of one molar acid increases the uranium indication by $15 \%$. Therefore, when nitric acid is present in a uranyl nitrate solution an accurate measurement cannot be obtained unless the acid concentration is held relatively constant and the instrument is calibrated with solutions that contain the normal acid concentration.

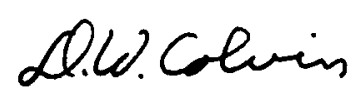

D. W. Colvin Applied Physics Division

\section{BIBLIOGRAPHY}

1. Thurnau, D. H. A Gamma Absorptometer for the Continuous Analysis of Solutions of Heavy Metal Salts. E. I. du Pont de Nemours \& Co., Aiken, S. C. AEC Research and Development Report DP-249, 31 pp. (1957).

2. Prohaska, C. A. A Flow Colorimeter for Measuring Uranium Concentration in Process Streams. E. I. du Pont de Nemours \& Co., A1ken, S. C. AEC Research and Development Report DP-229, 20 pp. (1957).

3. Herold, T. R. and E. C. Wingfield. A Degasser for In-Line Instrumental Analysis. E. I. du Pont de Nemours \& Co., Aiken, S. C. AEC Research and Development Report DP-276, 12 pp. (1958). 


\section{APPENDIX \\ CALCULATION OF OPTIMUM CELL THICKNESS}

The transmission of light through a solution at an absorption wave length of the chemical in the solution may be expressed by the equation

$$
I_{A}=I_{O} e^{-E C T}
$$

The symbols are defined as follows.

$$
\begin{aligned}
& I_{A}=\text { intensity of the light beam emerging from the solution } \\
& I_{O}=\begin{array}{l}
\text { intensity of the light beam emerging when the chemical } \\
\quad \text { concentration is zero }
\end{array} \\
& E=\text { molar extinction coefficient of the chemical, } \\
& \quad \text { liter } /(\operatorname{mol})(\mathrm{cm}) \\
& C=\text { concentration of the chemical, mol/liter } \\
& T=\text { thickness of the cell, } \mathrm{cm}
\end{aligned}
$$

In the colorimeter, the intensity of the absorption beam is compared with a reference beam that is not attenuated by the chemical to be measured. The intensity ratio of the two beams is taken and indicated on a recorder that is wired to produce an upscale deflection for increased absorption.

Recorder indication, $R=-\frac{I_{A} \text { (Intensity of Absorption beam) }}{I_{R} \text { (Intensity of Reference beam) }}$

or

$$
R=-\left[\frac{I_{0} e^{-E C T}}{I_{R}}\right]
$$

The sensitivity of the instmment may be defined as

$$
\frac{d R}{d C}=\frac{I_{O}}{I_{R}} E T e^{-E C T}
$$
To find the cell thickness for a maximum $\frac{d R}{d C}$ and a given $E$ and $C$ the
following expression may be used.

$$
\frac{d\left(\frac{d R}{d C}\right)}{d T}=0
$$


or

$$
\frac{d\left(\frac{d R}{d C}\right)}{d T}=\frac{I_{0}}{I_{R}} E e^{-E C T}(I-E C T)=0
$$

and

$$
\mathrm{T}=\frac{1}{\mathrm{EC}}
$$

It may be shown that this is a maximum by substituting values of $\mathrm{T}<$ and $>\frac{1}{\mathrm{EC}}$ in equation ( 3 ).

If the molar extinction coefficient is unknown for the chemical being measured, the optimum thickness may be found with the instrument by using a standard cell of known thickness and filling the cell with the concentration of the chemical for which the optimum thickness is to be found.

Solving equation ( 1 ) for $E$ and substituting for the celi thickness, $T_{1}$, used in the measurement yields the equation

$$
\begin{gathered}
E=\frac{I}{C T_{1}} \ln \frac{I_{0}}{I_{A}} \\
I_{O}=K_{1} I_{O} \\
I_{A}=K_{2} I_{A} \\
I_{O}=\text { current in measuring channel at zero concentration } \\
{ }^{1}=\begin{array}{c}
\text { current in measuring channel at concentration for optimum } \\
\text { thickness }
\end{array}
\end{gathered}
$$

$K_{1}$ and $K_{2}$ are constants and $K_{1}=K_{2}$ if the instrument gain controls are not changed during the measurement. Therefore

$$
\mathrm{E}=\frac{1}{\mathrm{CT}_{1}} \ln \frac{i_{0}}{i_{\mathrm{A}}}
$$

Substituting for $E$ in equation (4) yields the equation

$$
\mathrm{T}=\frac{\mathrm{T}_{1}}{\ln 1_{0}-\ln i_{\mathrm{A}}}
$$

Therefore, if values of $1_{O}$ and $1_{A}$ are determined with any convenient cell thickness, $\mathrm{T}_{1}$, the optimum thickness, $\mathrm{T}$, may be calculated. 


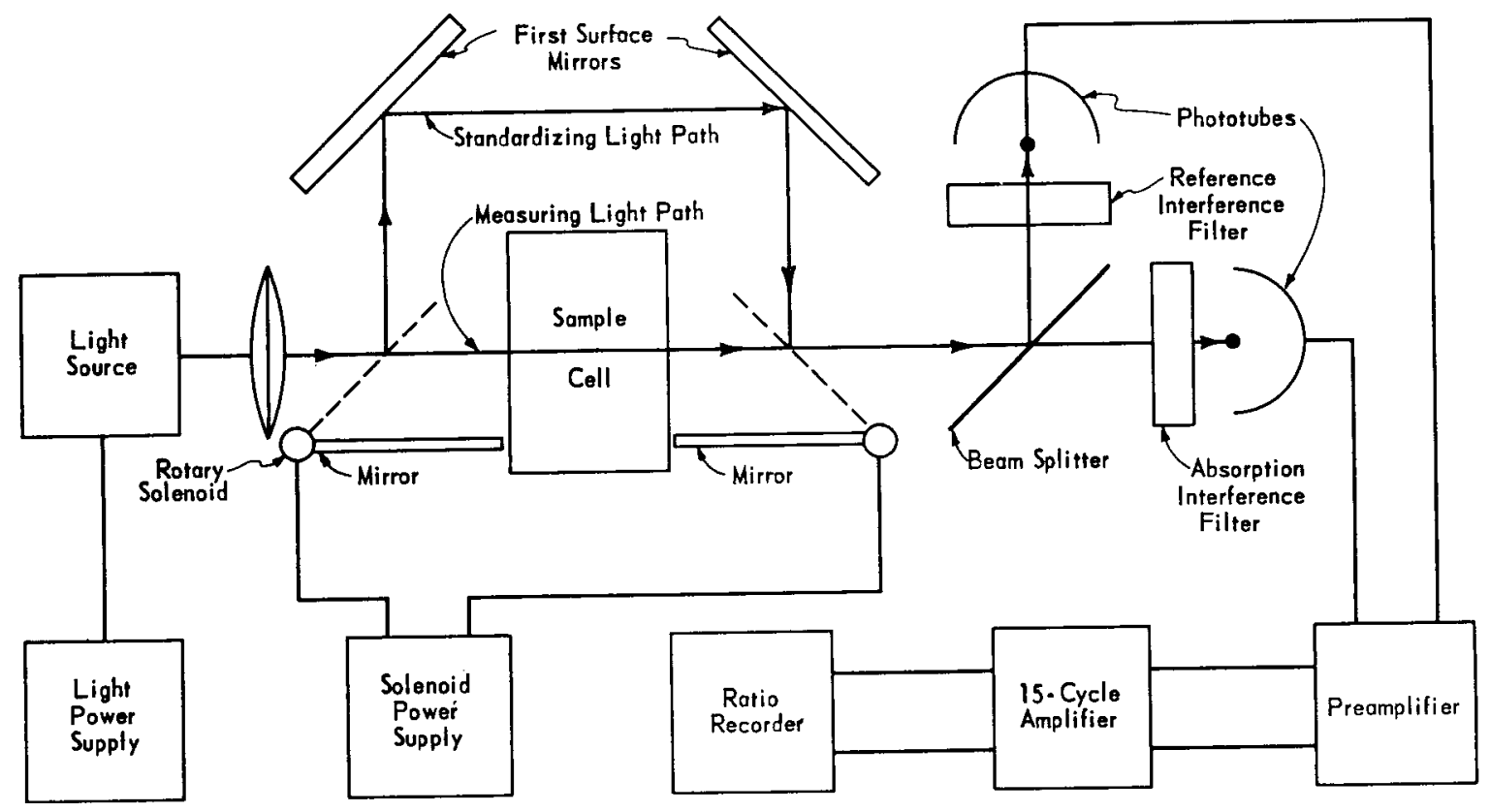

\begin{tabular}{|l|c|c|}
\hline \multirow{2}{*}{ Compound } & \multicolumn{2}{|c|}{ Wave Length of } \\
\cline { 2 - 3 } & Absorpterference Filters \\
\cline { 2 - 3 } $\mathrm{Pu}\left(\mathrm{NO}_{3}\right)_{3}$ & $564 \mathrm{~m} \mu$ & Reference \\
$\mathrm{Pu}\left(\mathrm{NO}_{3}\right)_{4}$ & $476 \mathrm{~m} \mu$ & $490 \mathrm{~m}_{\mu}$ \\
$\mathrm{UO}_{2}\left(\mathrm{NO}_{3}\right)_{2}$ & $416 \mathrm{~m} \mu$ & $515 \mathrm{~m} \mu$ \\
\hline
\end{tabular}

FIGURE 1 - FUNCTIONAL DIAGRAM OF THE COLORIMETER 


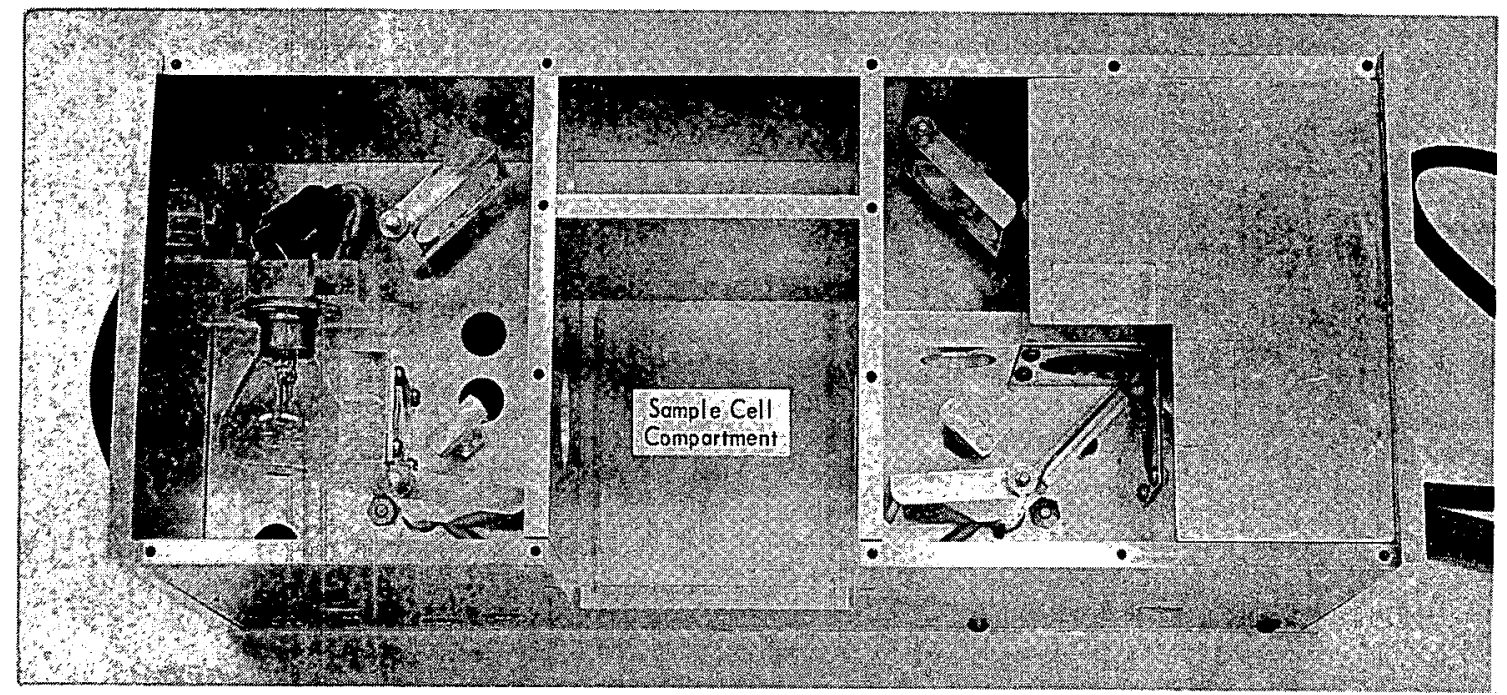

Top View

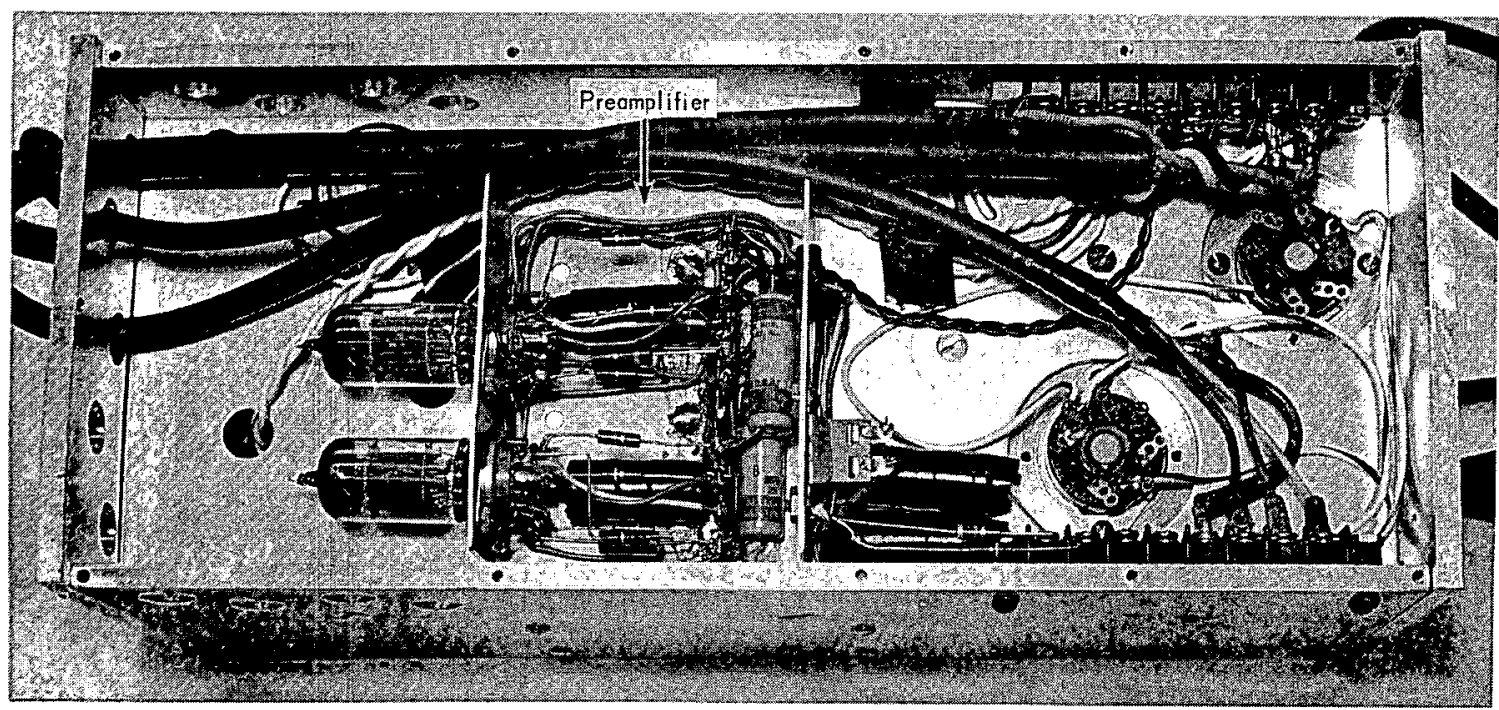

Bottom View

FIGURE 2 - PHOTOGRAPH OF THE COLORIMETER OPTICS HOUSING 


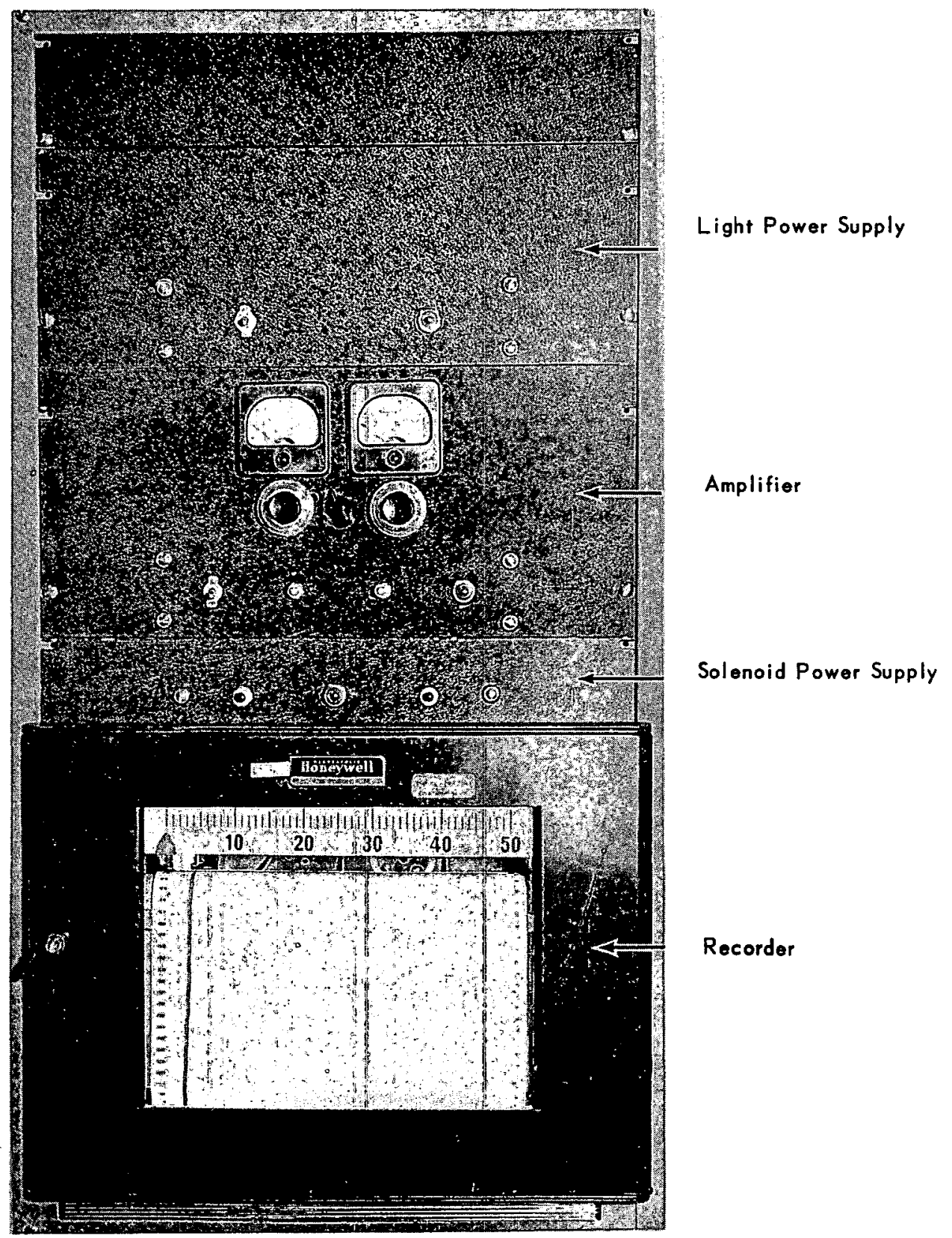

FIGURE 3 - PHOTOGRAPH OF THE COLORIMETER MEASURING SYSTEM 


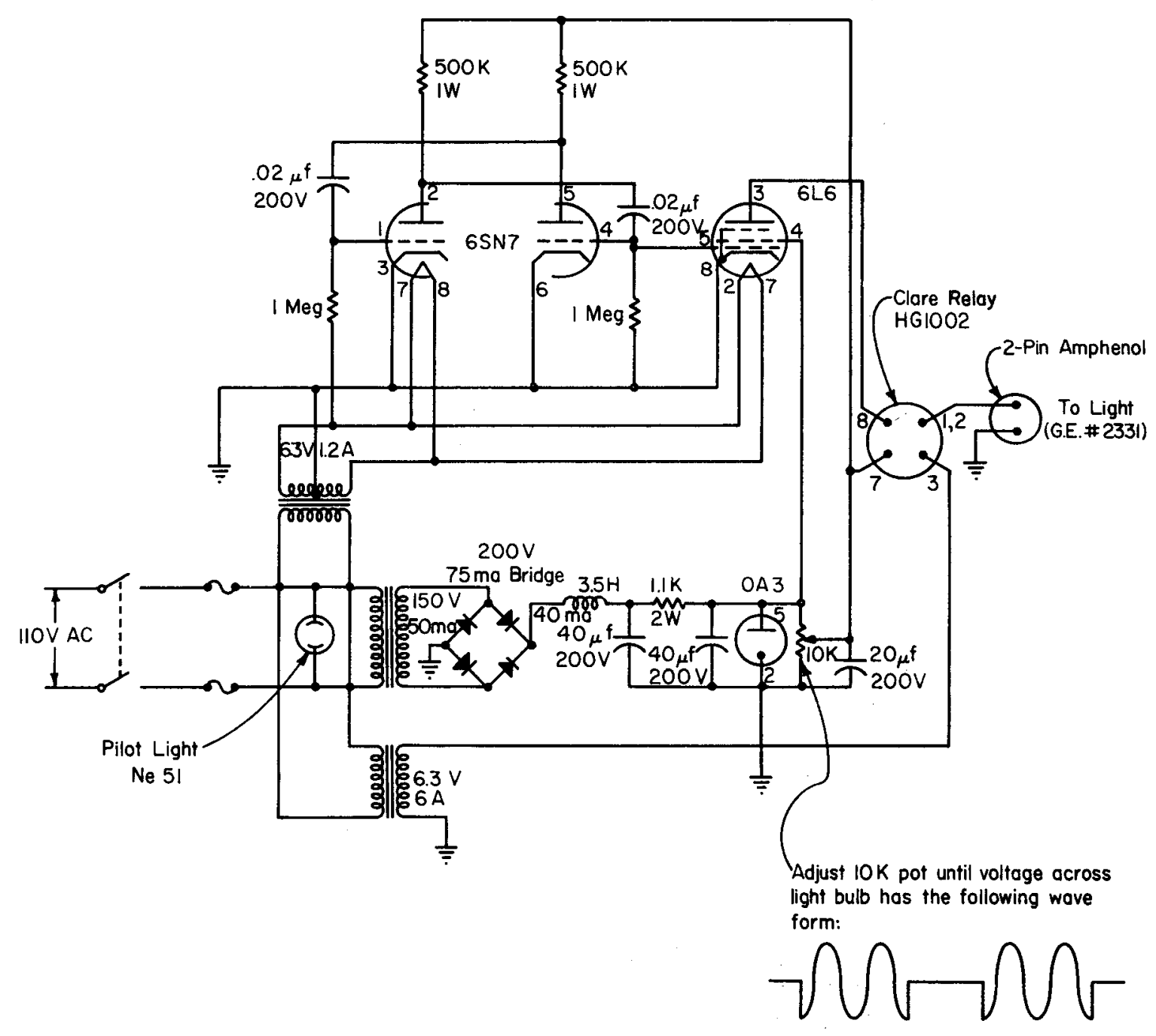

FIGURE 4 - LIGHT POWER SUPPLY 


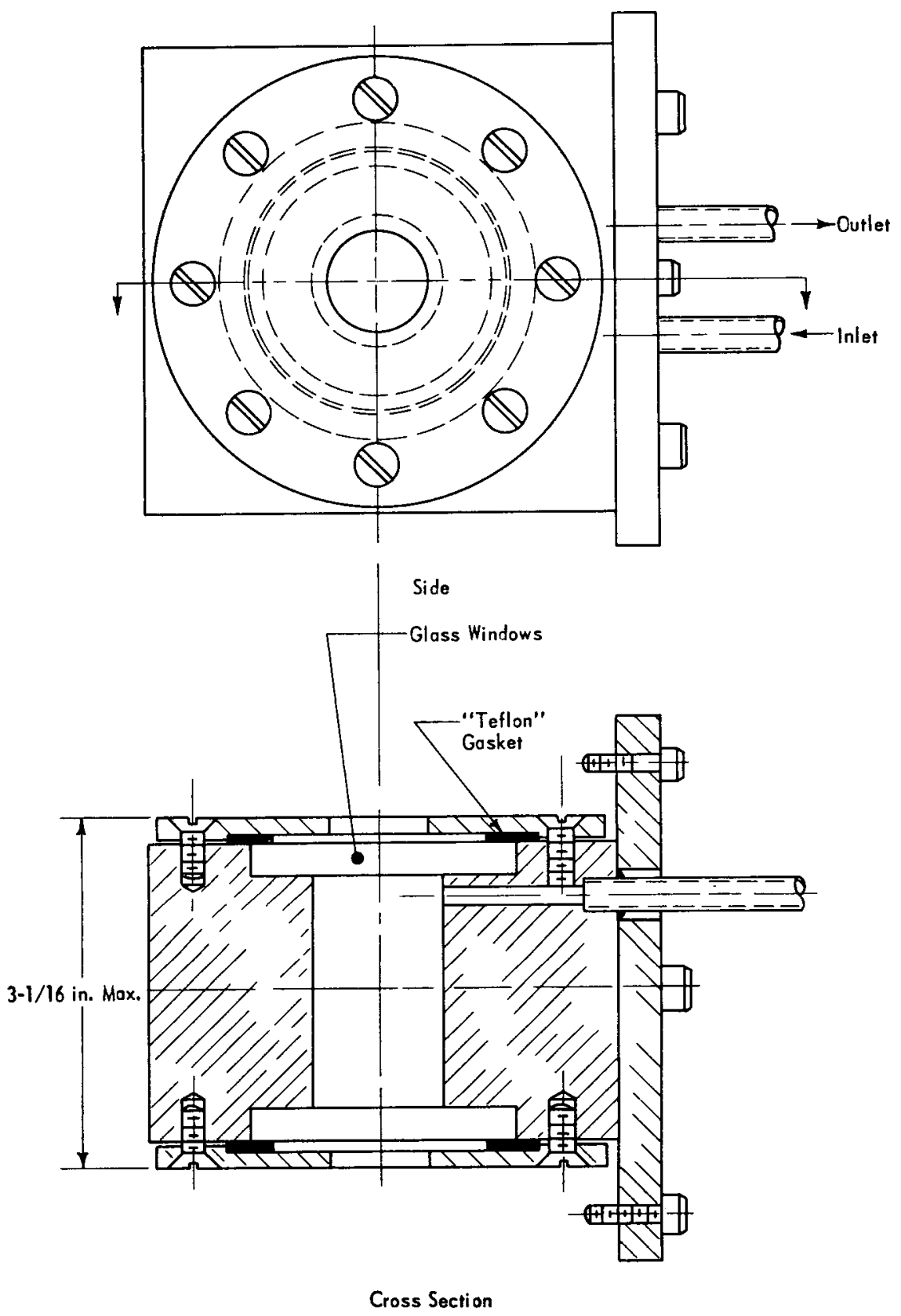

FIGURE 5 - SAMPLE CELL 


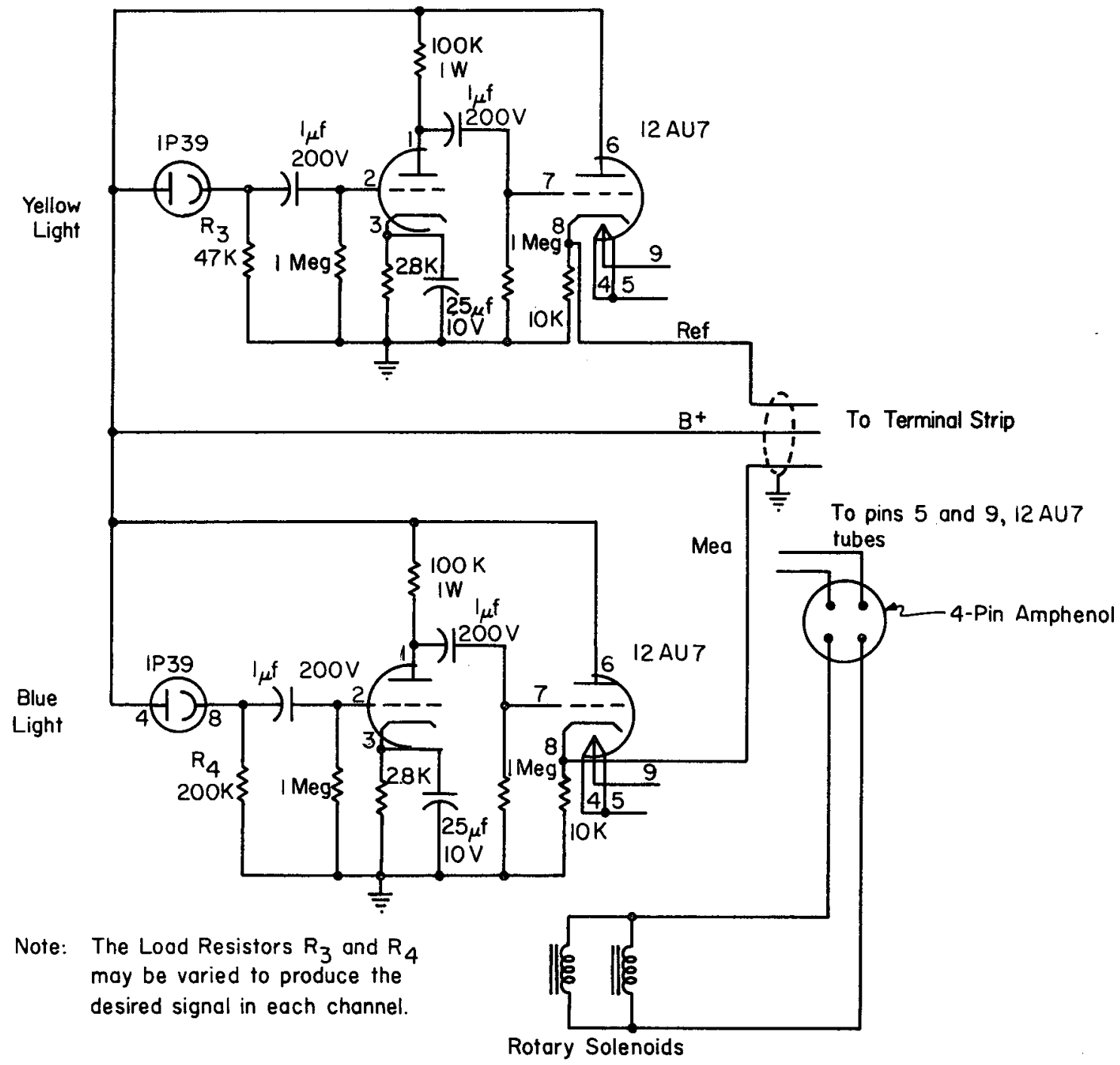

FIGURE 6 - PREAMPLIFIER CIRCUIT 


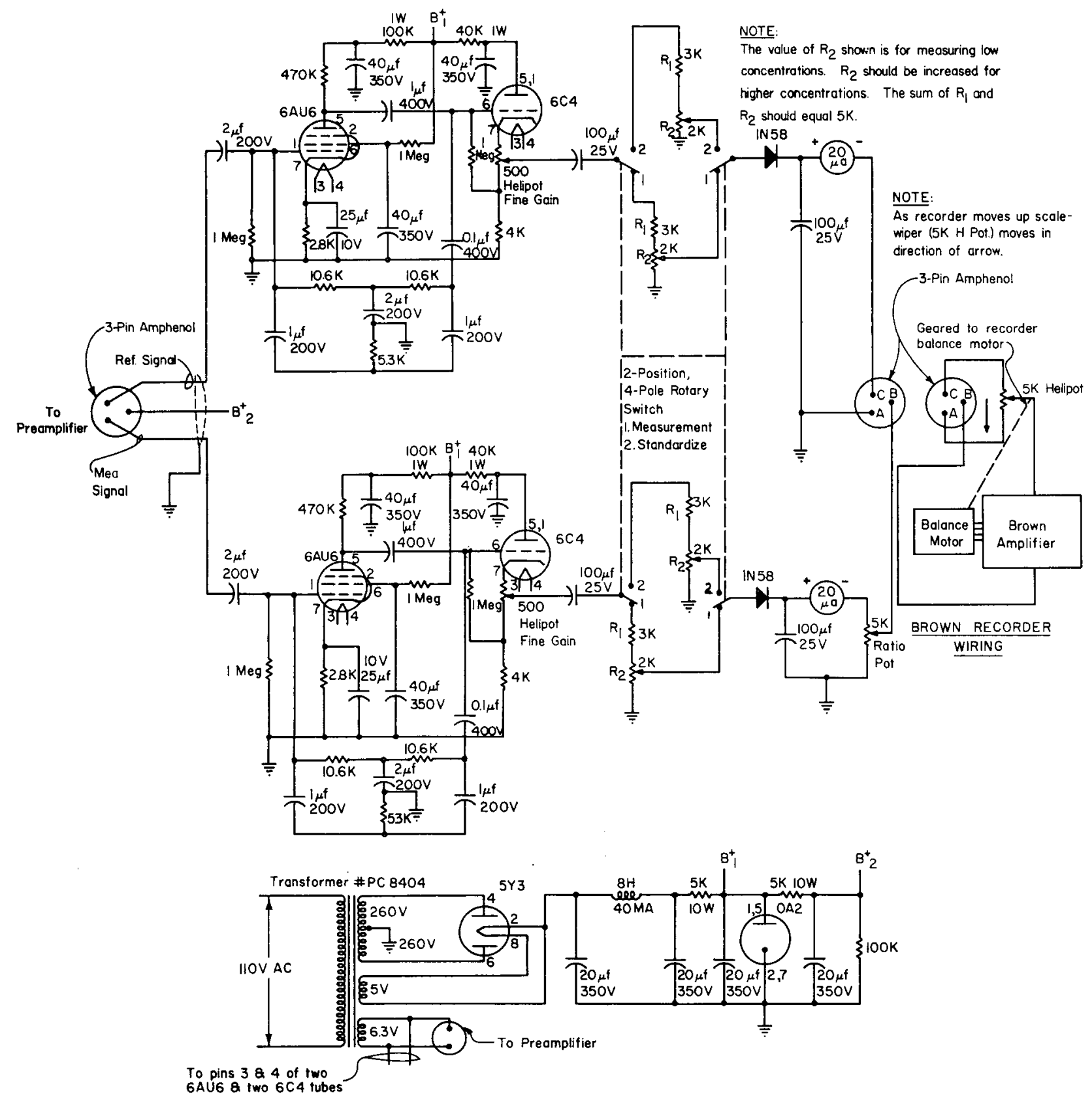

FIGURE 7 - AMPLIFIER CIRCUIT 


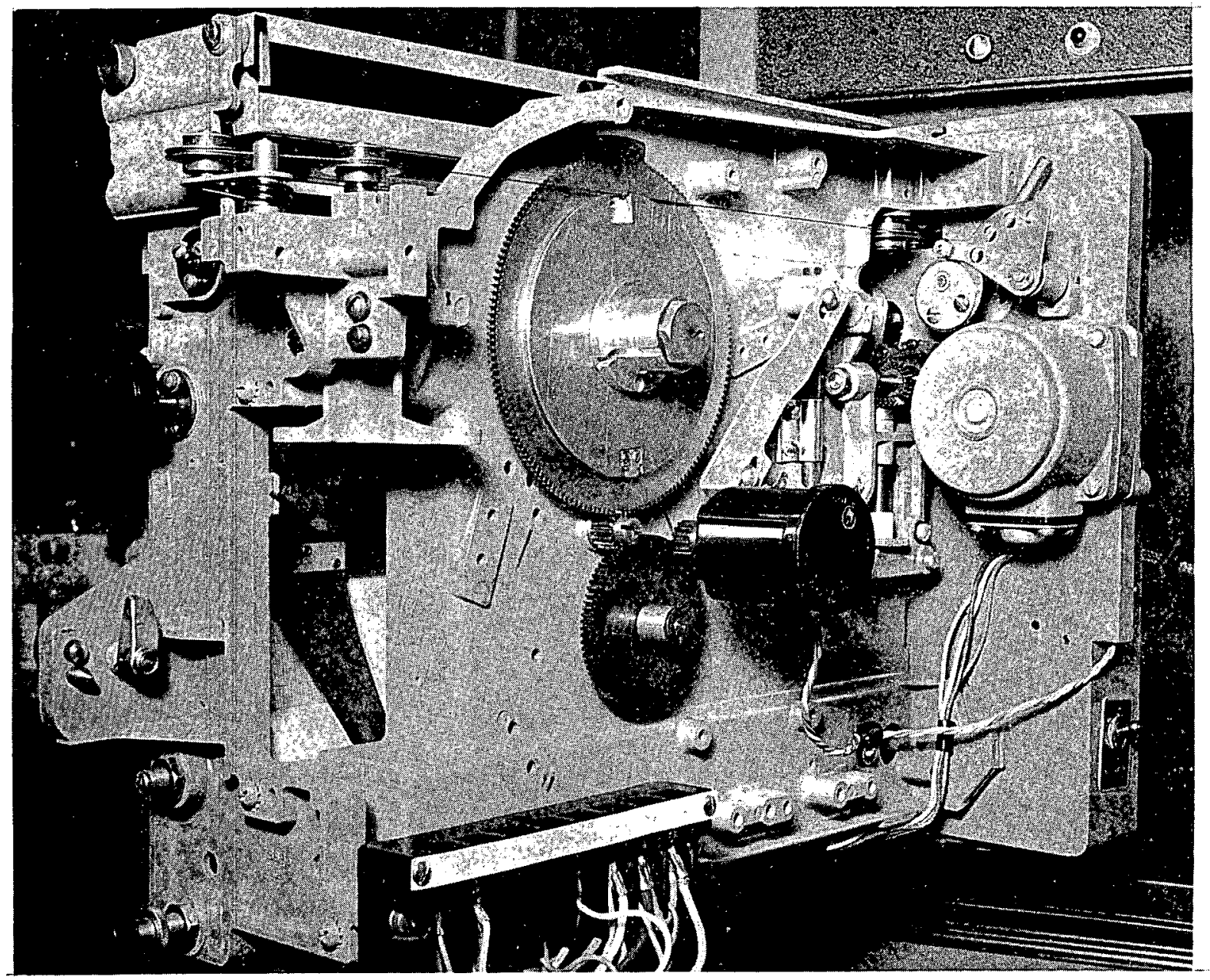

FIGURE 8 - MODIFICATION OF BROWN RECORDER 


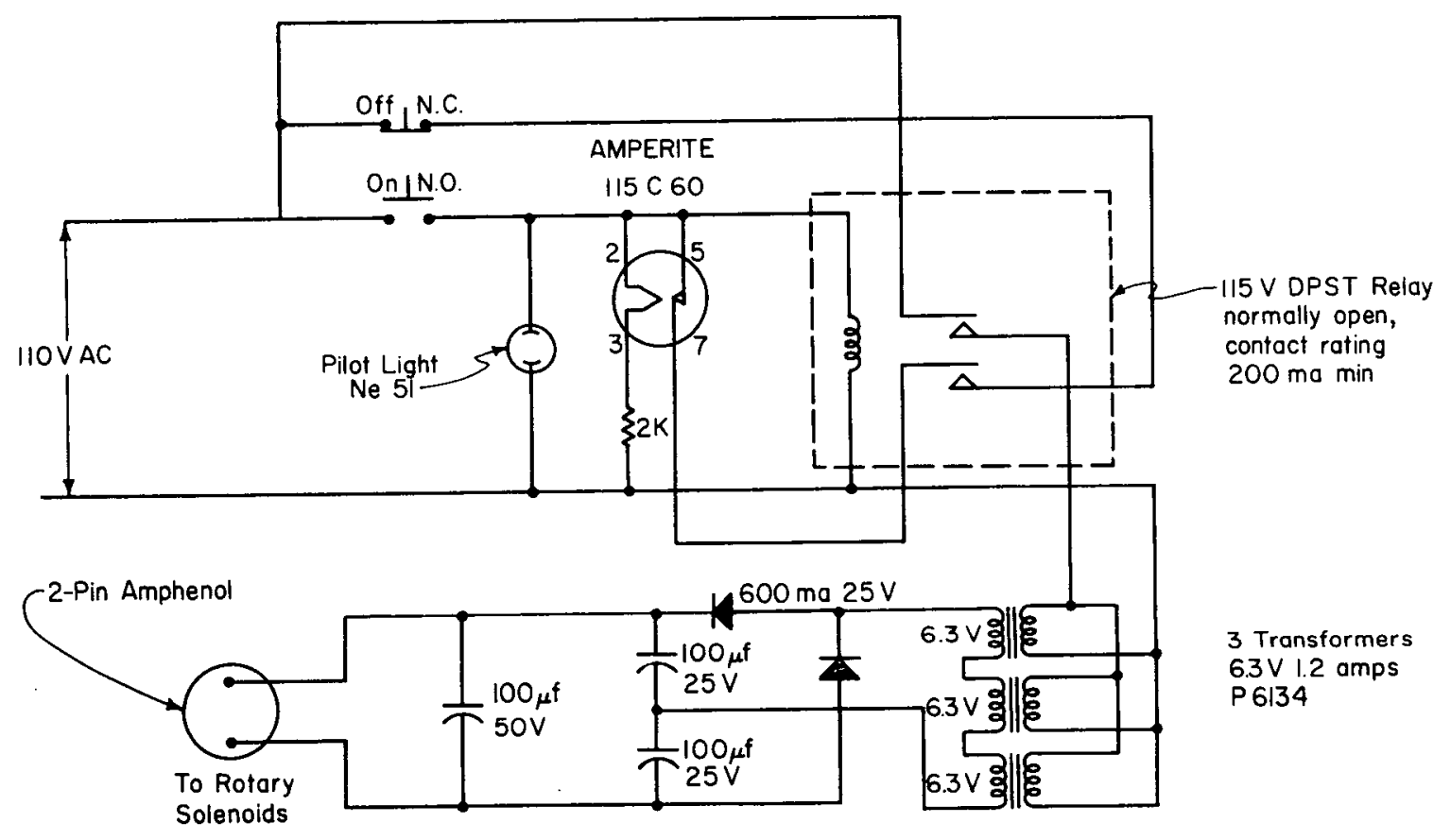

FIGURE 9 - SOLENOID POWER SUPPLY 


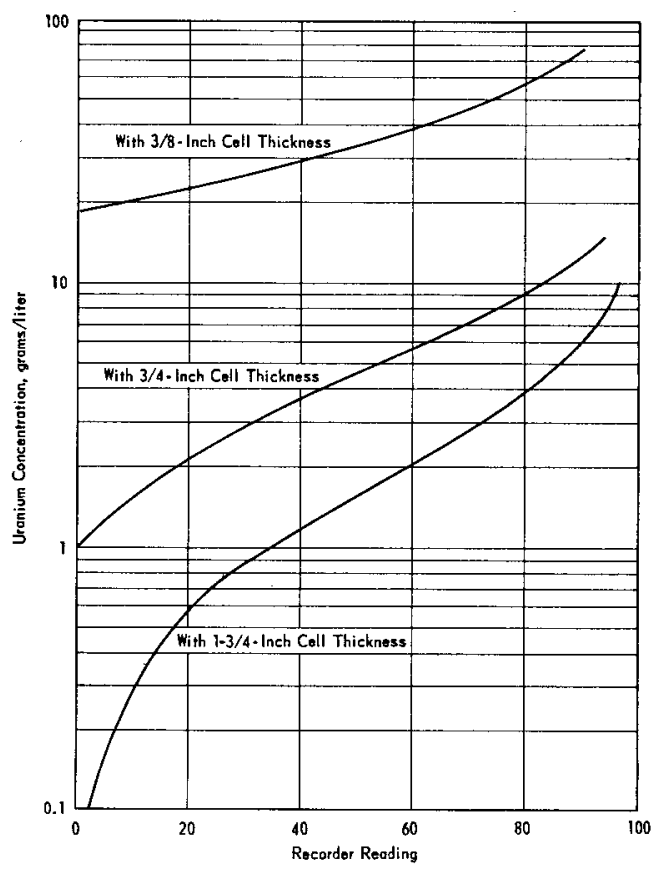

FIGURE 10 - CALIBRATION CURVES FOR URANYL NITRATE

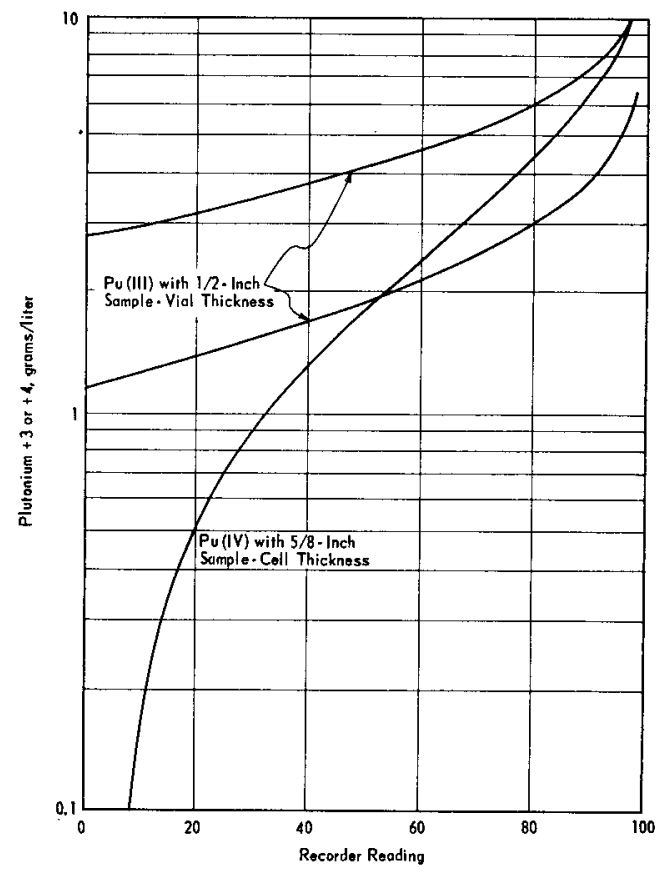

FIGURE 11 - CALIBRATION CURVES FOR PLUTONIUM NITRATE 

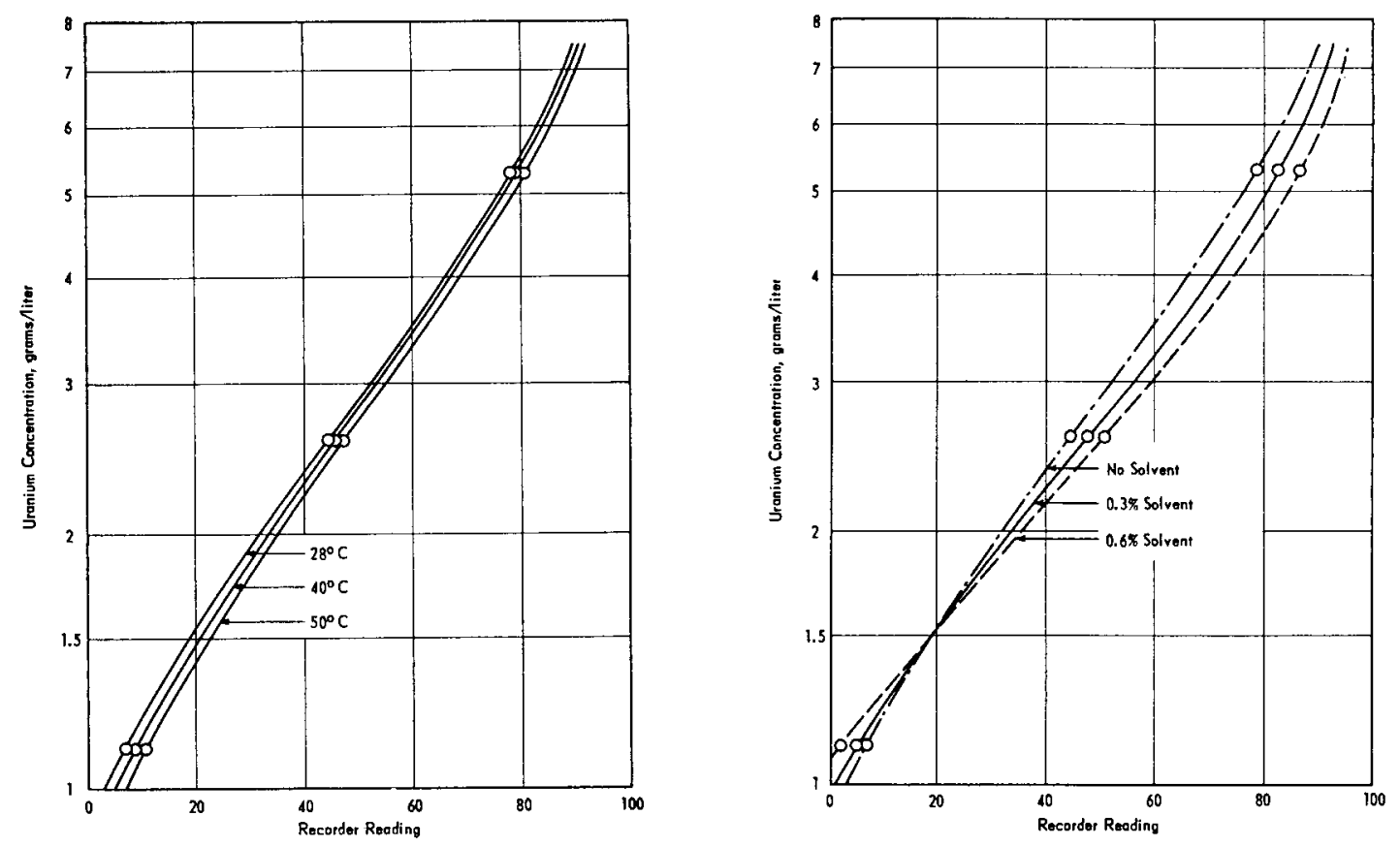

FIGURE 12 - EFFECT OF TEMPERATURE ON COLORIMETER MEASUREMENT

FIGURE 13 - EFFECT OF TURBIDITY ON COLORIMETER MEASUREMENT

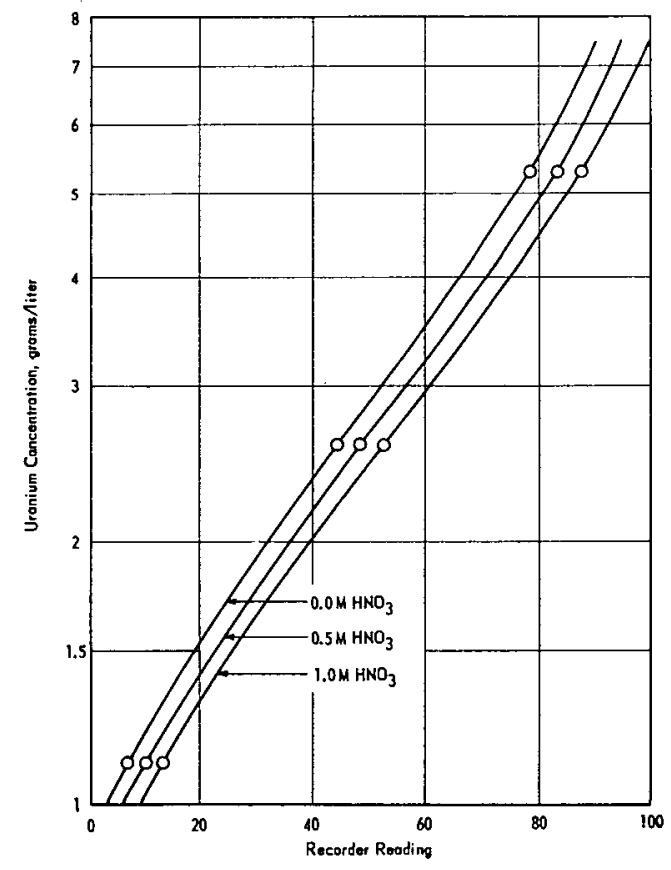

FIGURE 14 - EFFECT OF NITRIC ACID ON COLORIMETER MEASUREMENT 